\title{
Tissue Carnitine Reserves of Newborn Infants
}

\author{
JAYANT P. SHENAI ${ }^{(20)}$ AND PEGGY R. BORUM \\ Departments of Pediatrics [J.S.] and Biochemistry [P.B.], Vanderbilt University Medical Center, Nashville, \\ Tennessee, USA
}

\begin{abstract}
Summary
This study assessed the tissue reserves of carnitine at birth in a group of neonates $(n=22)$ of varying gestational age dying within $24 \mathrm{~h}$ of birth, prior to possible changes in carnitine status induced by postnatal intervention. Tissue carnitine concentration was highest in the muscle in each infant. The mean $( \pm \mathrm{SD})$ muscle carnitine concentration of $8.4 \pm 3.6 \mathrm{nmol} / \mathrm{mg}$ noncollagen protein (NCP) in very immature infants $(\leqslant 1000 \mathrm{~g}$ birth weight) was significantly lower than the corresponding mean $( \pm \mathrm{SD})$ values of $14.0 \pm 3.2 \mathrm{nmol} / \mathrm{mg} \mathrm{NCP}$ in larger preterm infants $(1001-2500$ $\mathrm{g} ; P<0.01)$ and $19.4 \pm 2.6 \mathrm{nmol} / \mathrm{mg} \mathrm{NCP}$ in term infants $(\geqslant 2501$ g; $P<0.001)$. Muscle carnitine concentration correlated positively with gestational age $(r=0.832 ; P<0.001)$ and with body dimensions. Liver and heart carnitine concentrations did not correlate significantly with gestation or body dimensions. The mean $( \pm \mathrm{SD})$ liver carnitine concentration for all the neonates as a group was $4.1 \pm 1.5 \mathrm{nmol} / \mathrm{mg}$ NCP. The mean $( \pm S D)$ heart carnitine concentration was $4.7 \pm 1.3 \mathrm{nmol} / \mathrm{mg} \mathrm{NCP}$.

In comparison to adult controls, tissue carnitine concentrations were markedly lower in neonates, particularly in immature newborns. These data suggest that newborn infants, especially premature babies, are born with limited tissue reserves of carnitine and are therefore at an increased risk for developing carnitine deficiency and its adverse effects in the postnatal period, particularly if maintained on carnitine-free intravenous nutrition for prolonged periods of time.
\end{abstract}

\section{Abbreviation}

NCP, noncollagen protein

Carnitine, $\beta$-OH- $\gamma$-trimethylaminobutyric acid, is a quaternary amine that plays an essential role in the oxidation of long chain fatty acids by facilitating their transport across the inner mitochondrial membrane (3). Adequate blood and tissue concentrations of carnitine may be important in enhancing utilization of fat and energy, and in promoting growth in neonates. We have previously shown that, at birth, the concentrations of carnitine in blood are higher in preterm infants than in neonates of term gestation, probably reflecting enhanced transplacental acquisition or decreased tissue uptake of carnitine in the preterm period (16). This study assessed the tissue reserves of carnitine at birth in a group of neonates dying within $24 \mathrm{~h}$ of birth, prior to possible changes in carnitine status induced by postnatal nutritional manipulation or therapeutic intervention.

\section{MATERIALS AND METHODS}

Subjects. Tissue samples were obtained at autopsy from 22 neonates who expired in the neonatal intensive care unit at Vanderbilt Medical Center. The clinical characteristics of infants are summarized in Table 1 . These infants (male $=9$, female $=$ 13) were 22 to 41 weeks in gestation (mean $\pm \mathrm{SD} ; 29.0 \pm 5.0$ weeks). Their birth weights ranged from 470 to $3580 \mathrm{~g}$ (mean \pm $\mathrm{SD} ; 1302 \pm 839 \mathrm{~g}$ ). Fifteen infants were born within the hospital; the remainder were transferred from other hospitals within $4 \mathrm{~h}$ of birth. Seventeen infants were white; the remainder were black. None of the infants showed evidence of growth retardation or congenital anomalies. Multiple births were excluded from the study. Death occurred within $24 \mathrm{~h}$ of birth in all cases. Massive intraventricular hemorrhage was the predominant cause of death in preterm neonates. Death was secondary to severe birth asphyxia in term neonates. None of the infants received exogenous carnitine during their brief postnatal life. Only intravenous glucose solution was provided during this period.

Autopsy procedures. Permission for a full autopsy was obtained from the parents in each case. The autopsy was performed within $12 \mathrm{~h}$ of death in all cases. Tissue carnitine concentrations are reported to remain unchanged in autopsy specimens up to $72 \mathrm{~h}$ after death (10). Muscle tissue was obtained from the right and/ or left psoas muscle. Liver tissue was obtained from the central portion of the right lobe. Myocardial tissue was obtained from the apex of the heart. The tissues were placed in separate, labeled, tightly capped plastic containers protected from direct light and frozen at $-60^{\circ} \mathrm{C}$ until analysis.

Chemical procedures. Tissue carnitine concentrations were measured by modification (16) of the method of Cederblad and Lindstedt (5). Noncollagen protein was solubilized by the method of Lilienthal et al. (12) and the concentration was assayed by the microbiuret method (11). The results are expressed as $\mathrm{nmol} / \mathrm{mg}$ $\mathrm{NCP}$ and $\mathrm{nmol} / \mathrm{g}$ wet weight. The values represent total carnitine concentrations.

Statistical analysis. Statistical analyses (mean, standard deviation, linear regression, correlation coefficient, and Student's $t$ test) were performed by using a Hewlett-Packard HP-55 programmable calculator.

\section{RESULTS}

Among the tissues analyzed, the highest carnitine concentration was found in the muscle in each infant. The mean muscle carnitine concentration (Table 2) was significantly lower in very immature infants $(\leqslant 1000 \mathrm{~g}$ birth weight) than in larger preterm infants $(1001-2500 \mathrm{~g} ; P<0.01)$, and than in infants of term gestation $(\geqslant 2501 \mathrm{~g} ; P<0.001)$. Linear regression analysis (Fig. 1) showed a significant positive correlation between muscle carnitine and gestational age $(r=0.832 ; P<0.001)$. Likewise, muscle carnitine concentration correlated positively with birthweight $(r=0.746 ; P<0.001)$, occipitofrontal circumference $(r$ $=0.791 ; P<0.001)$, and crown-heel length $(r=0.794, P<$ $0.001)$. The mean $( \pm \mathrm{SD})$ muscle carnitine concentration of 12.8 $\pm 6.9 \mathrm{nmol} / \mathrm{mg} \mathrm{NCP}$ in male infants did not differ significantly from the corresponding mean $( \pm \mathrm{SD})$ value of $11.8 \pm 3.6 \mathrm{nmol} /$ $\mathrm{mg}$ NCP in female infants. Likewise, the mean $( \pm S D)$ values for muscle carnitine did not differ significantly between white $(10.2$ $\pm 4.3 \mathrm{nmol} / \mathrm{mg} \mathrm{NCP})$ and black $(8.2 \pm 3.5 \mathrm{nmol} / \mathrm{mg} \mathrm{NCP})$ infants when matched for gestational age. 
Table 1. Clinical characteristics of neonates

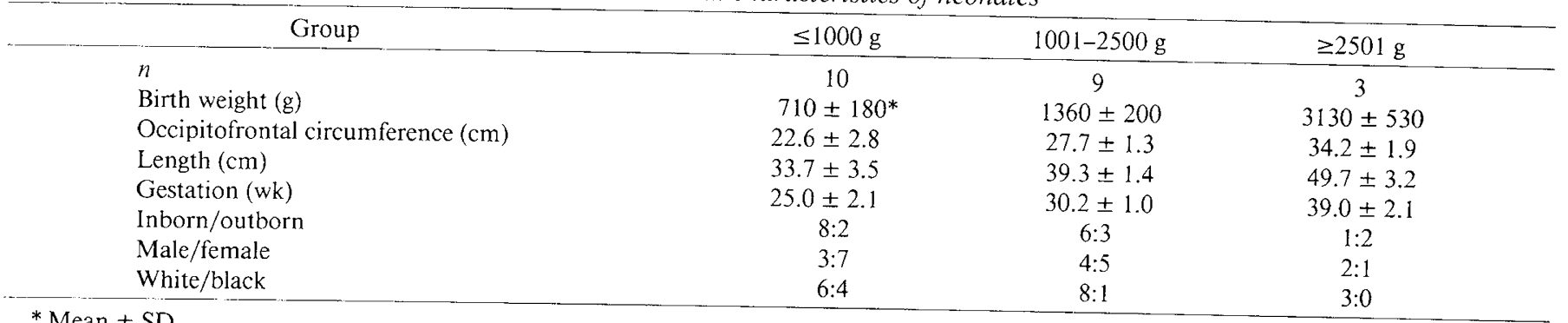

Table 2. Tissue carnitine concentrations in neonates

\begin{tabular}{cccc}
\hline Group & $\leq 1000 \mathrm{~g}$ & $1001-2500 \mathrm{~g}$ & $\geq 2501 \mathrm{~g}$ \\
\hline Muscle & & & \\
$\quad \mathrm{nmol} / \mathrm{mg} \mathrm{NCP}$ & $8.4 \pm 3.6$ & $14.0 \pm 3.2$ & $19.4 \pm 2.6$ \\
$\quad \mathrm{nmol} / \mathrm{g}$ wet weight & $817 \pm 414$ & $1463 \pm 444$ & $2168 \pm 468$ \\
Liver & & & \\
$\quad \mathrm{nmol} / \mathrm{mg} \mathrm{NCP}$ & $3.9 \pm 1.4$ & $4.2 \pm 1.5$ & $4.6 \pm 1.8$ \\
$\quad \mathrm{nmol} / \mathrm{g}$ wet weight & $474 \pm 172$ & $495 \pm 134$ & $489 \pm 155$ \\
Heart & & & \\
$\quad \mathrm{nmol} / \mathrm{mg} \mathrm{NCP}$ & $5.0 \pm 1.3$ & $4.3 \pm 1.4$ & $5.6 \pm 0.8$ \\
$\quad \mathrm{nmol} / \mathrm{g}$ wet weight & $498 \pm 188$ & $458 \pm 162$ & $543 \pm 98$ \\
\hline
\end{tabular}

The mean liver carnitine concentrations in very immature, larger preterm, and term infants did not differ significantly among the groups (Table 2$)$. The mean $( \pm S D)$ value for all the neonates as a group was $4.1 \pm 1.5 \mathrm{nmol} / \mathrm{mg} \mathrm{NCP}(485 \pm 147$ $\mathrm{nmol} / \mathrm{g}$ wet weight). The mean $( \pm \mathrm{SD})$ liver carnitine concentration of $3.1 \pm 0.9 \mathrm{nmol} / \mathrm{mg} \mathrm{NCP}$ in male infants was significantly lower than the corresponding mean $( \pm \mathrm{SD})$ value of $4.9 \pm 1.4$ $\mathrm{nmol} / \mathrm{mg} \mathrm{NCP}$ in female infants $(P<0.01)$. The mean $( \pm \mathrm{SD})$ values for liver carnitine did not differ significantly between white $(3.7 \pm 0.9 \mathrm{nmol} / \mathrm{mg} \mathrm{NCP})$ and black $(4.0 \pm 1.9 \mathrm{nmol} / \mathrm{mg}$ NCP) infants when matched for gestational age. Linear regression analysis did not show a significant correlation between liver carnitine and gestational age or body dimensions.

The mean heart carnitine concentrations in very immature, larger preterm, and term infants did not differ significantly

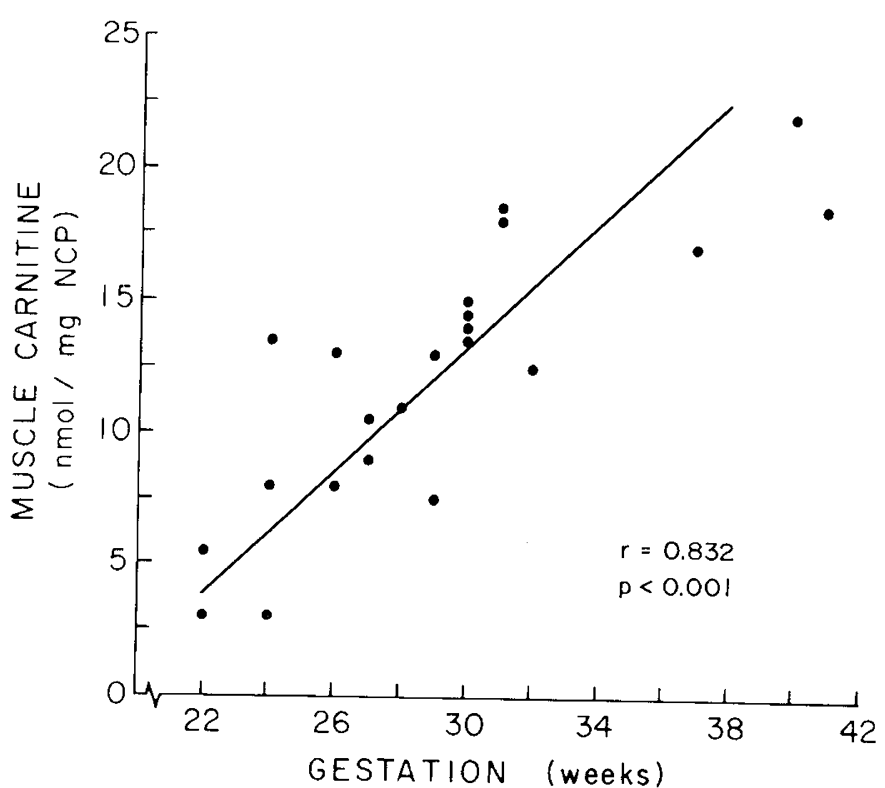

Fig. 1. Muscle carnitine concentrations plotted against gestational age. Regression is statistically significant $(r=0.832 ; P<0.001$; regression equation: $y=0.84 x+18.84$ ) among the groups (Table 2$)$. The mean $( \pm \mathrm{SD})$ value for all the neonates as a group was $4.7 \pm 1.3 \mathrm{nmol} / \mathrm{mg} \mathrm{NCP}(484 \pm 165$ $\mathrm{nmol} / \mathrm{g}$ wet weight). The mean $( \pm \mathrm{SD})$ values for heart carnitine did not differ significantly with respect to sex (male: $4.9 \pm 1.4$; female: $4.6 \pm 1.3 \mathrm{nmol} / \mathrm{mg} \mathrm{NCP}$ ) or race (white: $5.0 \pm 1.4$; black $4.6 \pm 1.3 \mathrm{nmol} / \mathrm{mg} \mathrm{NCP}$ ) when infants were matched for gestational age. Linear regression analysis did not show a significant correlation between heart carnitine and gestational age or body dimensions. No significant correlations were observed when individual tissue carnitine concentrations were analyzed by linear regression for intertissue relationships.

\section{DISCUSSION}

Carnitine is stored mainly in the skeletal muscle, although other tissues such as the heart, adrenal gland, liver, and adipose tissue contain significant amounts of carnitine (13). Normal concentration (mean $\pm \mathrm{SD}$ ) of muscle carnitine measured by our laboratory in healthy adult humans with histologically normal muscle biopsies is $27.0 \pm 7.3 \mathrm{nmol} / \mathrm{mg} \mathrm{NCP}(n=22)$ for males and $20.3 \pm 5.9 \mathrm{nmol} / \mathrm{mg} \operatorname{NCP}(n=16)$ for females. Similar studies are lacking in neonates, older infants, and children. This study provides new data on muscle carnitine reserves of neonates at birth, prior to possible changes in carnitine status induced by postnatal intervention.

The data suggest that muscle is the principal site of carnitine storage in neonates as it is in adults. Muscle carnitine stores increase with advancing gestation during fetal life. This observation may be a reflection of increased availability of carnitine through transplacental acquisition or endogenous synthesis, enhanced tissue uptake and storage of carnitine, or decreased utilization of carnitine with advancing maturation during fetal life. In comparison to adult controls, the muscle carnitine concentrations are markedly lower in neonates, particularly in immature newborns. The potential ability of preterm neonates to offset an inadequate carnitine intake in the postnatal period may therefore be poor. A progressive decline in muscle carnitine concentration has been observed within about 2 weeks of postnatal life in preterm neonates maintained on carnitine-free intravenous nutrition (14). Our laboratory has shown that the muscle carnitine concentrations of the rat normally increase significantly from birth to weaning (4).

The principal site of carnitine synthesis from the amino acids lysine and methionine is believed to be the liver, although other tissues such as the kidney are capable of carnitine synthesis in certain animal species and in humans $(2,15)$. Liver carnitine concentration is largely determined by the rate of synthesis of carnitine and its release to the peripheral tissues. Hepatic $\gamma$ butyrobetaine hydroxylase enzyme activity is often used as a measure of the capacity for carnitine synthesis (2). The release of carnitine from the liver to the peripheral tissues remains uninvestigated in humans. Normal concentration (mean \pm SD) of liver carnitine measured by our laboratory in histologically normal liver tissues obtained at autopsy in adults is $7.8 \pm 3.1$ $\mathrm{nmol} / \mathrm{mg} \mathrm{NCP}(n=5)$. In comparison to these adult controls, the liver carnitine concentrations are markedly lower in newborn 
infants irrespective of their gestational age. This difference may be attributed to the limited capacity of neonates for endogenous synthesis of carnitine. There is evidence to suggest that hepatic $\gamma$-butyrobetaine hydroxylase enzyme activity is age dependent. Studies in rats have shown that the ability of the liver to synthesize carnitine from $\gamma$-butyrobetaine increases from low values in the fetus to adult values on the 8th day after birth (9). Studies from a limited number of young infants indicate that the hepatic $\gamma$-butyrobetaine hydroxylase enzyme activity is only $12 \%$ of the normal adult activity (15). The difference in liver carnitine concentrations between males and females observed in this study remains unexplained.

Muscle weakness and clinical symptoms consistent with hypoglycemia are the predominant features associated with carnitine deficiency in humans $(6,8)$. Cardiac enlargement accompanied by congestive heart failure, which may prove to be fatal has been noted in occasional patients with carnitine deficiency (7). Tripp et al. (17) have described a family in which cardiomyopathy secondary to endocardial fibroelastosis and systemic carnitine deficiency occurred in a number of offspring. These implications of cardiac involvement in syndromes of carnitine deficiency highlight the need to establish normal ranges for heart carnitine concentration in humans. This study provides new data on heart carnitine concentrations in a large number of neonates of varying gestation. Normal concentration (mean $\pm \mathrm{SD}$ ) of heart carnitine measured by our laboratory in histologically normal heart tissues obtained at autopsy in adults is $9.3 \pm 5.4 \mathrm{nmol} / \mathrm{mg}$ NCP $(n=6)$. In comparison to these adult controls, the heart carnitine concentrations are markedly lower in newborn infants irrespective of their gestational age. This difference is probably a reflection of varying maturation. Carnitine concentrations are low in the heart of the rat at birth, but increase during the suckling period (4). Likewise, carnitine levels in cardiac muscle are reported to increase during normal human development (1). On the contrary, a progressive decline in cardiac carnitine concentration has been reported within about 2 weeks of postnatal life in preterm neonates maintained on carnitine-free intravenous nutrition (14).

In summary, we have measured tissue carnitine concentrations in neonates of varying gestation dying within $24 \mathrm{~h}$ of birth. The data suggest that these infants, especially those of preterm gestation, are born with limited tissue reserves of carnitine and are therefore at an increased risk for developing carnitine deficiency and its adverse effects in the postnatal period, particularly if maintained on carnitine-free intravenous nutrition for prolonged periods of time.

\section{REFERENCES AND NOTES}

1. Angelini C, Battistella PA, Verigani L 1978 Carnitine deficiency states in human tissue in induced conditions and normal development, abstracts. In Aguayo AJ, Karpati G (eds) IV International Congress of Neuromuscular Diseases (abstr), Montreal, Canada, Sept 17-21, 1978. Elsevier/North-Holland, Montreal, p 474

2. Bohmer T 1974 Conversion of butyrobetaine to carnitine in the rat in vivo. Biochim Biophys Acta 343:551

3. Borum PR 1981 Possible carnitine requirement of the newborn and the effect of genetic disease on the carnitine requirement. Nutr Rev 39:385

4. Borum P 1978 Variation in tissue carnitine concentrations with age and sex in the rat. Biochem J 176:677

5. Cederblad G, Lindstedt S 1972 A method for the determination of carnitine in the picomole range. Clin Chim Acta 37:235

6. Chapoy PR, Angelini C, Brown WJ, Stiff JE, Shug AL, Cederbaum SD 1980 Systemic carnitine deficiency - a treatable inherited lipid-storage disease presenting as Reye's syndrome. N Engl J Med 303:1389

7. Engel AG 1980 Possible causes and effects of carnitine deficiency in man. In Frenkel RA, McGarry JD (eds): Carnitine Biosynthesis, Metabolism, and Functions. Academic Press, New York, pp 271-285

8. Engel AG, Angelini C 1973 Carnitine deficiency of human skeletal muscle with associated lipid storage myopathy: a new syndrome. Science 179:899

9. Hahn P 1981 The development of carnitine synthesis from $\gamma$-butyrobetaine in the rat. Life Sci 28:1057

10. Ikeakor IP, Lake BD 1978 Carnitine levels in children. Clin Chim Acta 82:197

11. Itzhaki RF, Gill DM 1964 A micro-biuret method for estimating proteins Anal Biochem 9:40

12. Lilienthal JL, Jr, Zierler KL, Folk BP, Buka B, Riley MJ 1950 A reference base and system for analysis of muscle constituents. J Biol Chem 182:501

13. Mitchell ME 1978 Carnitine metabolism in human subjects. I. Normal metabolism. Am J Clin Nutr 31:293

4. Penn D, Schmidt-Sommerfeld E, Pascu F 1981 Decreased tissue carnitine concentrations in newborn infants receiving total parenteral nutrition. Pediatr 98:976

15. Rebouche CJ 1980 Comparative aspects of carnitine biosynthesis in microorganisms and mammals, with special attention to carnitine biosynthesis in man. In: Frenkel RA, McGarry JD (eds): Carnitine Biosynthesis, Metabolism, and Functions. Academic Press, New York, p 57

16. Shenai JP, Borum PR, Mohan P. DonLevy SC 1983 Carnitine status at birth of newborn infants of varying gestation. Pediatr Res 17:579

17. Tripp ME, Katcher ML, Peters HA, Gilbert EF, Arya S, Hodach RJ, Shug AL 1981 Systemic carnitine deficiency as familial endocardial fibroelastosis. N Engl J Med 305:385

18. The authors gratefully acknowledge the expert technical assistance of Mrs. Carla M. York, Mrs. M. Collier, and Ms. Sandra G. Bennett.

19. This research was supported by Research Grants from The Nutrition Foundation and The Muscular Dystrophy Association of America.

20. Requests for reprints should be addressed to: Dr. Jayant P. Shenai, Departmen of Pediatrics, Vanderbilt University Medical Center, Nashville, TN 37232.

21. Received for publication September 26, 1983. 